\title{
Pengaruh Rangkaian Struktur Tenggelam Tidak Simetris Berbentuk Segitiga Terhadap Refleksi Gelombang
}

\author{
Sardi Pulu ${ }^{*}$, David Arin ${ }^{* 2}$, Erni Rante Bungin ${ }^{* 3}$, Mary Selitung ${ }^{\star 4}$ \\ *1,2 Mahasiswa Prodi Teknik Sipil, Universitas Kristen Indonesia Paulus, Makassar, Indonesia \\ Sardi Pulu'@yahoo.com, David arin@yahoo.com \\ *3,4 Dosen Prodi Teknik Sipil, Universitas Kristen Indonesia Paulus, Makassar, Indonesia \\ erni bungin@yahoo.co.id
}

\begin{abstract}
ABSTRAK
Beberapa negara termasuk Indonesia pada saat ini giat dalam mengembangkan kawasan pesisir (daerah pantai), terutama untuk tujuan mengamankan daerah pantai dari permasalahan erosi. Salah satu perlindungan pantai yang telah dibuat oleh manusia adalah struktur pemecah gelombang. Penelitian ini bertujuan untuk mengetahui pengaruh rangkaian struktur tenggelam tidak simetris berbentuk segitiga terhadap refleksi gelombang. Jenis penelitian yang digunakan adalah eksperimental, dimana kondisi tersebut dibuat dan diatur oleh peneliti, dengan demikian penelitian eksperimental adalah penelitian yang dilakukan dengan mengadakan manipulasi terhadap obyek penelitian. Didalam penelitian ini digunakan data primer berupa data yang diperoleh langsung dari simulasi model yang akan dilakukan dilaboratorium. Hasil penelitian menunjukkan bahwa nilai koefisien refleksi (Kr) bergantung pada pemilihan Stroke, Periode Gelombang (T), dan kedalaman air (d) dan hasil untuk pengaruh kerapatan model segitiga terhadap refleksi gelombang memperlihatkan dimana semakin besar jarak kerapatan antar model pemecah gelombang, maka nilai koefisien refleksi ( $K r$ ) yang dihasilkan semakin kecil dan sebaliknya.
\end{abstract}

Kata Kunci : pemecah gelombang, segitiga, kerapatan, koefisien refleksi

\begin{abstract}
Several countries, including Indonesia, are currently active in developing coastal areas (coastal areas), especially for the purpose of securing coastal areas from erosion problems. One of the coastal protection that has been made by humans is a breakwater structure. This study aims to determine the effect of a series of asymmetrical sink structures in the form of triangles on wave reflection. Type of research is experimental, where the conditions are made and regulated by researchers, thus experimental research is research conducted by manipulating research objects. In this study primary data is used in the form of data obtained directly from simulation models that will be carried out in the laboratory. The results show that the reflection coefficient $(\mathrm{Kr})$ depends on the selection of Stroke, Wave Period (T), and water depth (d) and the results for the effect of the density of the triangle model on wave reflection show where the greater the distance of density between the breakwater models, the value of the reflection coefficient $(\mathrm{Kr})$ produced is getting smaller and vice versa.
\end{abstract}

Keywords: breakwater, triangle, density, reflection coefficient

\section{PENDAHULUAN}

Beberapa negara termasuk Indonesia pada saat ini giat dalam mengembangkan kawasan pesisir (daerah pantai), terutama untuk tujuan mengamankan daerah pantai dari permasalahan erosi dan untuk kepentingan kawasan pariwisata. Pada umumnya manusia telah membuat mekanisme perlindungan pantai. Salah satu perlindungan pantai yang telah dibuat oleh manusia adalah struktur pemecah gelombang.
Breakwater atau pemecah gelombang merupakan pelindung utama bagi pelabuhan buatan [1]. Bangunan ini mempunyai fungsi sebagai alternatif untuk menjaga garis pantai dari gempuran ombak atau dengan mereduksi energi gelombang agar tidak sampai ke daerah pantai. . Pemecah gelombang dapat dibedakan menjadi dua macam yaitu pemecah gelombang sambung pantai dan lepas pantai. Tipe pertama banyak digunakan pada perlindungan perairan pelabuhan,sedangkan tipe kedua banyak digunakan untuk perlindungan pantai terhadap erosi. Pemecah gelombang tipe lepas pantai adalah 
bangunan yang dibuat sejajar dengan pantai dan berada pada jarak tertentu dari garis pantai.

Gelombang yang menjalar mengenai suatu bangunan peredam gelombang sebagian energinya akan dipantulkan (refleksi), sebagian diteruskan (transmisi), dan sebagian dihancurkan (disipasi) melalui pecahnya gelombang bergantung pada karakteristik gelombang datang seperti periode, tinggi gelombang, kedalaman air serta tipe bangunan peredam gelombang.

Tinjauan refleksi gelombang penting di dalam perencanaan bangunan pantai. Refleksi gelombang di pantai akan menyebabkan ketidaktenangan di dalam perairan, maka bangunan-bangunan yang ada di pantai harus dapat menyerap/menghancurkan energi gelombang.

Tujuan penelitian ini adalah untuk mengetahui parameter-parameter yang berpengaruh terhadap refleksi gelombang pada rangkaian struktur tenggelam tidak simetris dengan model fisik pemecah gelombang berbentuk segitiga dan untuk mengetahui pengaruh kerapatan model fisik pemecah gelombang dengan bentuk segitiga terhadap refleksi gelombang.

Parameter penting untuk menjelaskan gelombang air adalah panjang gelombang, tinggi gelombang dan kedalaman air dimana gelombang tersebut menjalar. Parameter-parameter yang lain seperti pengaruh kecepatan dapat ditentukan dari ketiga parameter pokok diatas. Adapun pengertian dari beberapa parameter diatas :

a. Panjang gelombang $(L)$ adalah jarak horizontal antara dua puncak atau titik tertinggi gelombang yang berurutan, bisa juga dikatakan sebagai jarak antara dua lembah gelombang (gT2).

b. Periode gelombang ( $\mathrm{T}$ ) adalah waktu yang dibutuhkan oleh dua puncak/lembah gelombang yang berurutan melewati suatu titik tertentu.

c. Kecepatan rambat gelombang (celerity) (C) adalah perbandingan antara panjang gelombang dan periode gelombang (L/T). ketika gelombang air menjalar dengan kecepatan C. partikel air tidak turut bergerak ke arah perambatan gelombang. Sedangkan sumbu koordinat untuk menjelaskan gerak gelombang berada pada kedalaman muka air tenang. Yaitu $\mathrm{z}=-\mathrm{h}$

d. Amplitudo (a) adalah jarak vertikal antara puncak/titik tertinggi gelombang atau lembah/titik terendah gelombang, dengan muka air tenang $(\mathrm{H} / 2)$. Gelombang terjadi karena hembusan angin di permukaan air. Daerah dimana gelombang dibentuk disebut daerah pembangkitan gelombang (wave generating area).

Pada saat gelombang bergerak menuju ke garis pantai (shoreline), gelombang mulai bergesekan dengan dasar laut dan menyebabkan pecahnya gelombang ditepi pantai. Hal ini juga dapat terjadi pengaruh pada garis pantai dan bangunan yang ada disekitarnya. Keenam peristiwa tersebut adalah :

a. Refraksi gelombang yakni peristiwa berbeloknya arah gerak puncak gelombang.

b. Difraksi gelombang yakni peristiwa berpindahnya energi di sepanjang puncak gelombang ke arah daerah yang terlindung.

c. Refleksi gelombang yakni peristiwa pemantulan energi gelombang yang biasanya disebabkan oleh suatu bidang bangunan di lokasi pantai.

d. Wave shoaling yakni peristiwa membesarnya tinggi gelombang saat bergerak ke tempat yang lebih dangkal.

e. Wave damping yakni peristiwa tereduksinya energi gelombang yang biasanya disebabkan adanya gaya gesekan dengan dasar pantai.

f. Wave breaking yakni peristiwa pecahnya gelombang yang biasanya terjadi pada saat gelombang mendekati garis pantai (surf zone).

Jika ditinjau dari kedalaman relatif dimana gelombang menjalar, maka gelombang dikelompokkan dalam 3 kategori yaitu gelombang laut dangkal, gelombang laut transisi dan gelombang laut dalam. Batasan dari ketiga kategori tersebut didasarkan pada rasio antara kedalaman dan panjang gelombang $(d / L)$. Batasan penggunaannya dapat dilihat pada Tabel 1 .

Tabel 1. Batasan gelombang

\begin{tabular}{cccc}
\hline $\begin{array}{c}\text { Kategori } \\
\text { Gelombang }\end{array}$ & $d / L$ & $2 \pi d / L$ & Tanh(2 $\pi d / L)$ \\
\hline Laut Dalam & $>0,5$ & $>\pi$ & $\approx 1$ \\
\hline
\end{tabular}

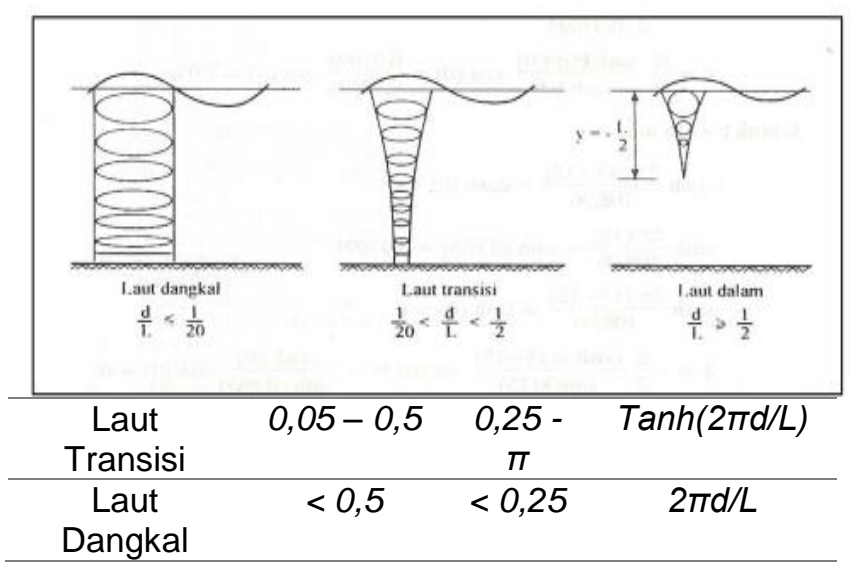

Dalam gelombang terdapat partikel-partikel air yang berubah selama penjalaran gelombang dari laut dalam sampai laut dangkal. Bentuk partikel yang terdapat dalam gelombang yang bergerak menuju laut dangkal digambarkan pada Gambar 1.

Gambar 1 : Gerak partikel air dalam gelombang 
Refleksi gelombang adalah gelombang datang yang mengenai suatu rintangan akan dipantulkan sebagian atau seluruhnya [2]. Tinjauan refleksi gelombang penting di dalam perencanaan bangunan pantai, terutama pada bangunan pelabuhan. Refleksi gelombang di dalam pelabuhan akan menyebabkan ketidaktenangan di dalam perairan. energi gelombang lebih banyak dibanding dengan bangunan tegak dan masif. Besar kemampuan suatu bangunan memantulkan gelombang diberikan oleh koefisien refleksi, yaitu perbandingan antara tinggi gelombang refleksi $\mathrm{Hr}$ dan tinggi gelombang datang $\mathrm{Hi}$ :

$\mathrm{Kr}=\mathrm{Hi} / \mathrm{Hi}$

dimana : $\mathrm{Kr}=$ Koefisien refleksi $; \mathrm{Hr}=$ Tinggi gelombang refleksi $(\mathrm{m}) ; \mathrm{Hi}=$ Tinggi gelombang datang $(\mathrm{m})$.

Koefisien refleksi bangunan diestimasi berdasarkan tes model. Koefisien refleksi berbagai tipe bangunan disajikan dalam tabel berikut ini :

Tabel 2 : Koefisien refleksi

\begin{tabular}{lc}
\hline \multicolumn{1}{c}{ Tipe Bangunan } & $\mathrm{Kr}$ \\
\hline $\begin{array}{l}\text { Dinding vertikal dengan puncak } \\
\text { diatas air }\end{array}$ & $0,7-1,0$ \\
Dinding vertikal dengan puncak & $0,5-0,7$ \\
terendam & $0,3-0,6$ \\
Tumpukan batu sisi miring & $0,3-0,5$ \\
Tumpukan blok beton dengan & $0,05-0,2$ \\
Bangunan vertikal dibang) & \\
peredam energi (diberi lubang
\end{tabular}

Dinding vertikal dan tak permiabel memantulkan sebagian gelombang. Pada bangunan seperti itu,koefisien refleksi adalah $X=1$, dan tinggi gelombang yang dipantulkan sama dengan tinggi gelombang datang. Gelombang di depan dinding vertical merupakan superposisi dari kedua gelombang dengan periode, tinggi dan angka gelombang yang sama tetapi berlawanan arah. Apabila Refleksi sempurna, $X=1$ maka :

$\mathrm{H}=\mathrm{Hi} \cos k x \cos \sigma \mathrm{t}$

dimana : $\mathrm{H}=$ tinggi gelombang $(\mathrm{m}) ; \mathrm{H}=$ tinggi gelombang datang $(\mathrm{m}) ; k=$ Bilangan gelombang ; $x$ $=$ Jarak penjalaran gelombang

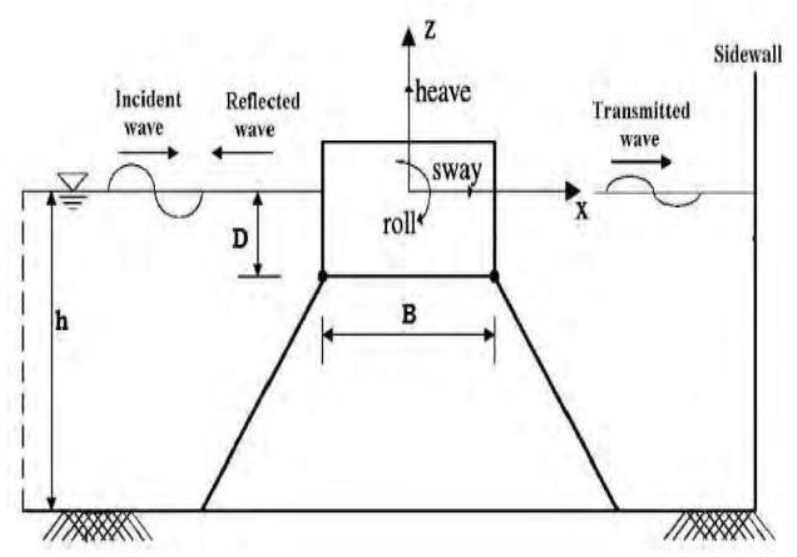

Gambar 2. Skema terjadinya refleksi gelombang

\section{Penelitian Terdahulu}

Studi pengamanan pantai tipe pemecah gelombang tenggelam di Pantai Tanjung Kait dengan hasil Hasil koefisien transmisi hasil simulasi pada kondisi sebelum struktur dan setelah struktur pada saat musim timur $75-78 \%$, sedangkan pada saat musim barat koefisen transmisi $62-65 \%$ [3].

Analisis efektifitas penggunaan Breakwater dengan lapis pelindung bambu dan tetrapod untuk mereduksi energi gelombang laut di Pelabuhan Kuala Tanjung dengan hasil Hasil perhitungan diperoleh untuk alternatif I dengan kelandaian cot $=1,5$ berat material per 1 meter panjang adalah $192 \mathrm{~kg}$ untuk bambu dan beton dan $397 \mathrm{~kg}$ untuk tetrapod. Alternatif II dengan kelandaian $\cot =2$, berat material per 1 meter panjang adalah $144 \mathrm{~kg}$ untuk bambu dan beton dan $298 \mathrm{~kg}$ untuk tetrapod. Alternatif III dengan kelandaian $\cot =3$, berat material per 1 meter panjang adalah $96 \mathrm{~kg}$ untuk bambu dan $198 \mathrm{~kg}$ untuk tetrapod [4].

Refleksi gelombang pada pemecah gelombang blok beton berkait menghasilkan nilai koefisien refleksi $34,7 \%$ pada saat $(h-d) / h=0$ dan lebar puncak $B=$ $2.0[5]$.

\section{METODOLOGI PENELITIAN}

Kegiatan penelitian ini dilakukan di Laboratorium Hidrolika dan Teknik Pantai pada Jurusan Teknik Sipil Fakultas Teknik Universitas Hassanudin di Gowa. Saluran gelombang yang mempunyai ukuran panjang saluran $15 \mathrm{~m}$, lebar saluran $0,3 \mathrm{~m}$, tinggi saluran $0,45 \mathrm{~m}$ dan kedalaman efektif saluran 0,45 $\mathrm{m}$.

Sebelum melaksanakan penelitian terlebih dahulu dilakukan perancangan model fisik sesuai dengan variabel yang akan diteliti. Model fisik yang digunakan memiliki dua ukuran yang akan 
dideskripsikan pada Gambar 3 dan 6, kerapatan model akan dideskripsikan pada Gambar 9.

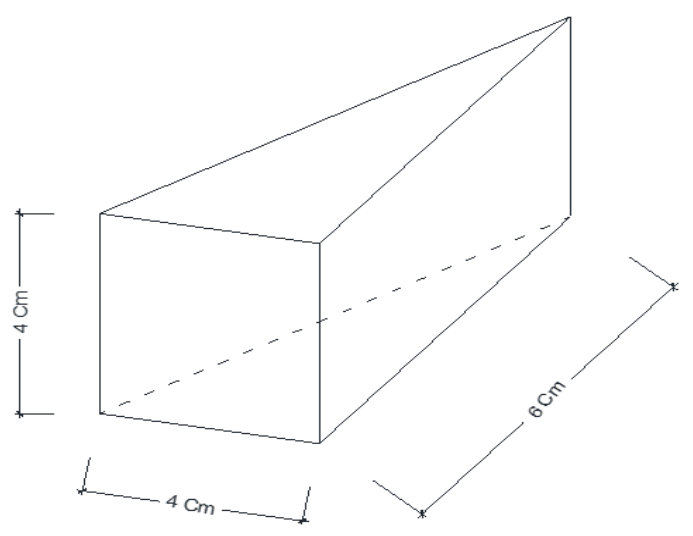

Gambar 3. Sketsa model fisik type A

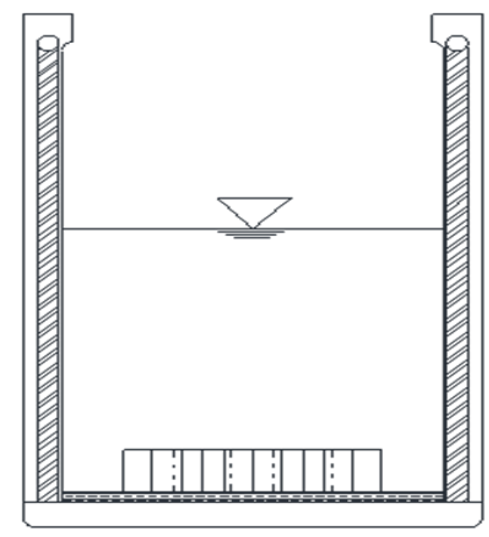

Gambar 4. Sketsa model fisik type A ( Tampak depan )

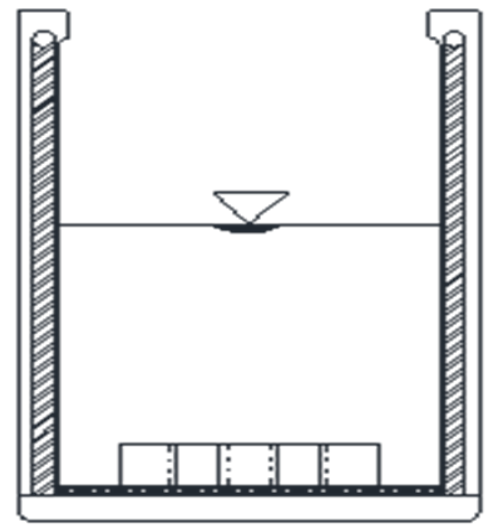

Gambar 5. Sketsa model fisik type A ( Tampak belakang )

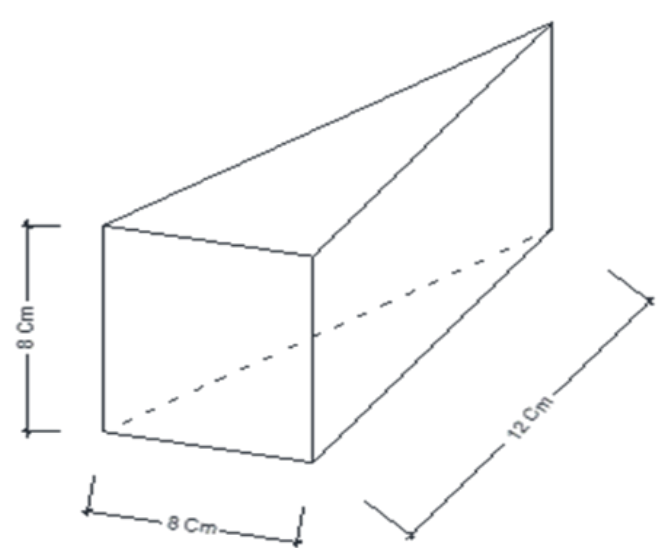

Gambar 6. Sketsa model fisik type B ( Tampak 3d )

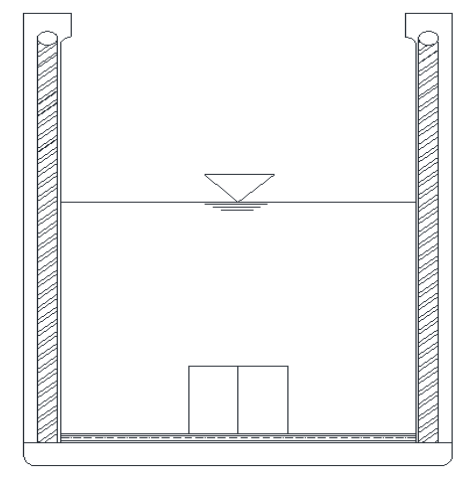

Gambar 7. Sketsa model fisik type B ( Tampak depan )

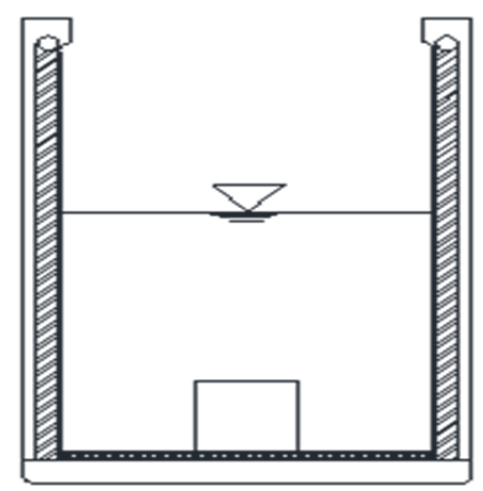

Gambar 8. Sketsa model fisik type B ( Tampak belakang ) 


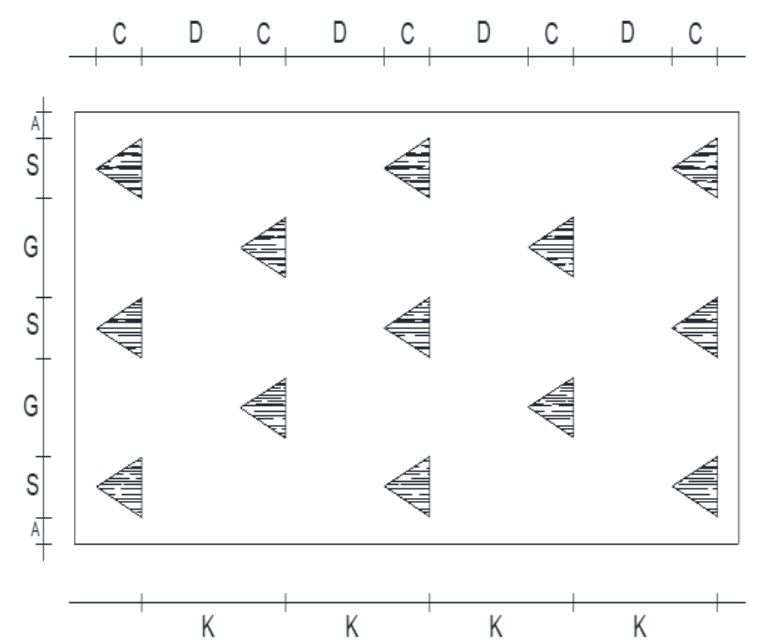

Gambar 9. Kerapatan model

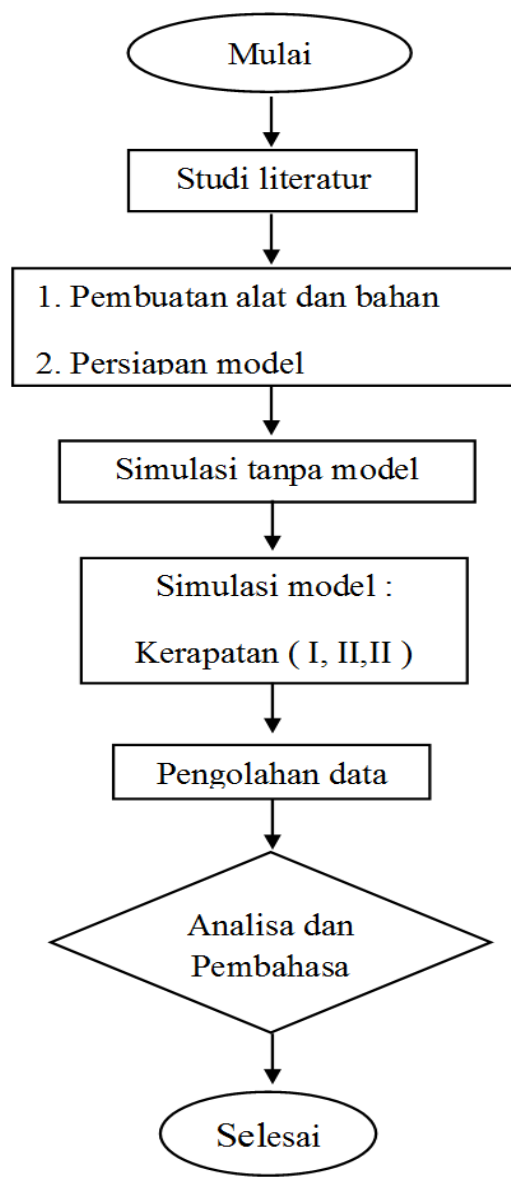

Gambar 10. Bagan alir penelitian

\section{HASIL DAN PEMBAHASAN}

Pada penelitian ini, terdapat 3 variasi kerapatan model untuk yakni kerapatan I, kerapatan II, dan kerapatan III dengan ukuran model $4 \times 6 \mathrm{~cm}$ dan satu model dengan ukuran $8 \times 12 \mathrm{~cm}$ sebagai pembanding. Pembahasan untuk hasil dari penelitian ini berupa grafik yang akan dijelaskan sebagai berikut.
Hubungan Koefisien Refleksi (Kr) terhadap kecuraman gelombang $(\mathrm{Hi} / \mathrm{L})$ untuk tiap model fisik dengan bentuk segitiga.

\section{Kerapatan I}

Nilai Koefisien Refleksi (Kr) akan semakin kecil ketika nilai Kecuraman gelombang $(\mathrm{Hi} / \mathrm{L})$ bertambah besar, dengan kata lain Koefisien Refleksi berbanding lurus dengan kecuraman gelombang.

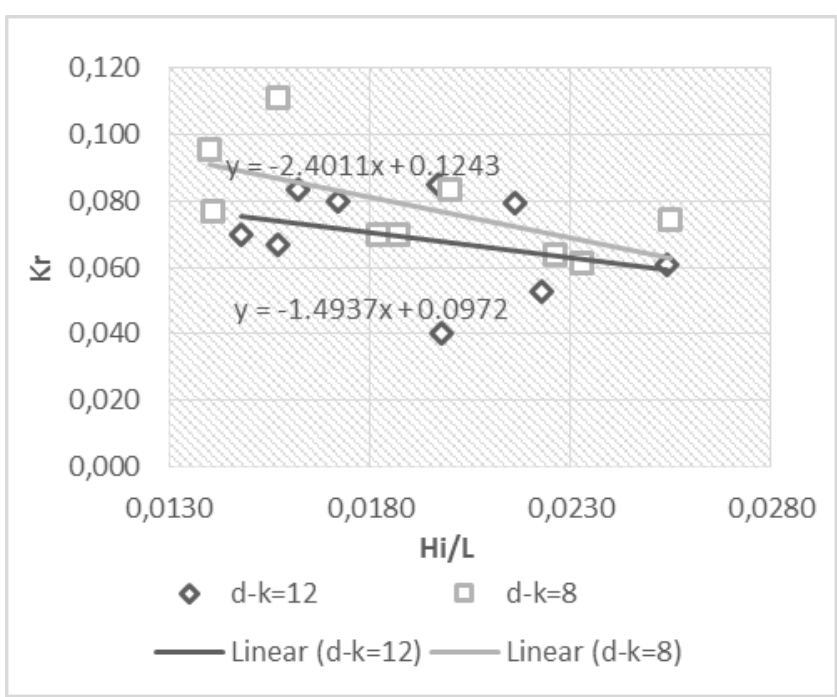

Gambar 11. Grafik Hubungan Krvs Hi/L

\section{Model Besar}

Berdasarkan grafik diatas, dapat dilihat bahwa nilai Koefisien Refleksi $(\mathrm{Kr})$ akan semakin kecil ketika nilai Kecuraman gelombang (Hi/L) bertambah besar, dengan kata lain Koefisien Refleksi berbanding lurus dengan kecuraman gelombang. Hubungan $\mathrm{Kr}$ dan $\mathrm{Hi} / \mathrm{L}$ dapat dilihat pada Gambar 12.

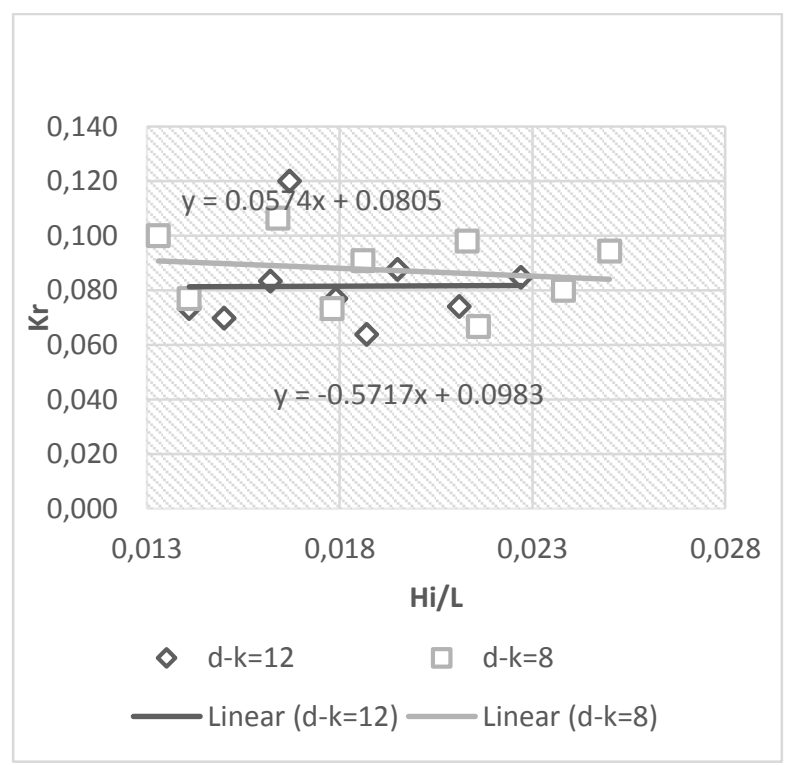

Gambar 12. Hubungan $K r$ dan $\mathrm{Hi} / \mathrm{L}$ 


\section{Pengaruh Model Fisik Tipe A Terhadap Refleksi Gelombang}

Nilai Koefisien Refleksi (Kr) akan semakin besar ketika nilai stroknya nya bertambah besar, dengan kata lain Koefisien Refleksi berbanding lurus dengan nilai stroke.

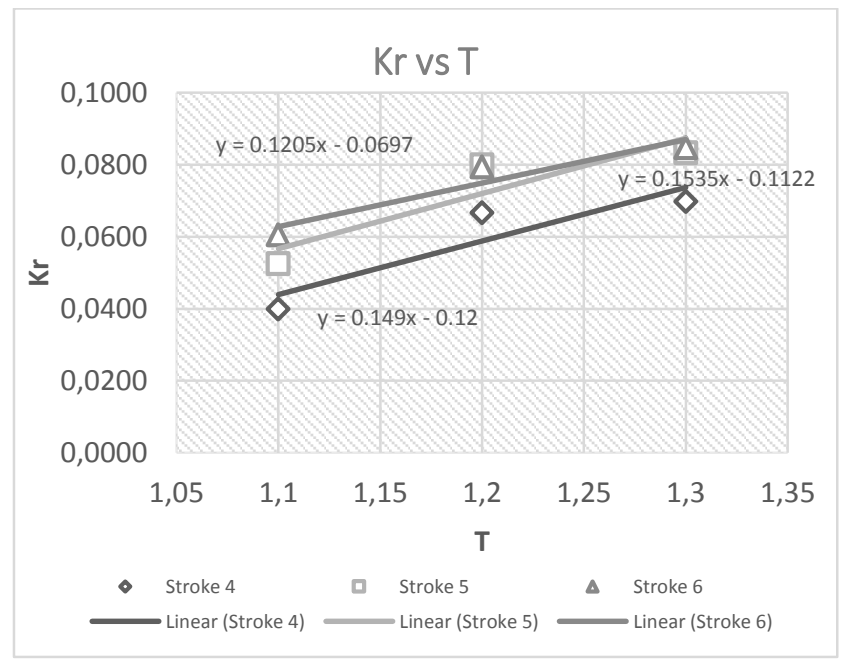

Gambar 13. Grafik hubungan $K r$ dan Stroke model tipe $A, d=16 \mathrm{~cm}$

Nilai Koefisien Refleksi (Kr) akan semakin besar ketika nilai Periodenya (T) nya bertambah besar, dengan kata lain Koefisien Refleksi berbanding lurus dengan Periode gelombang.

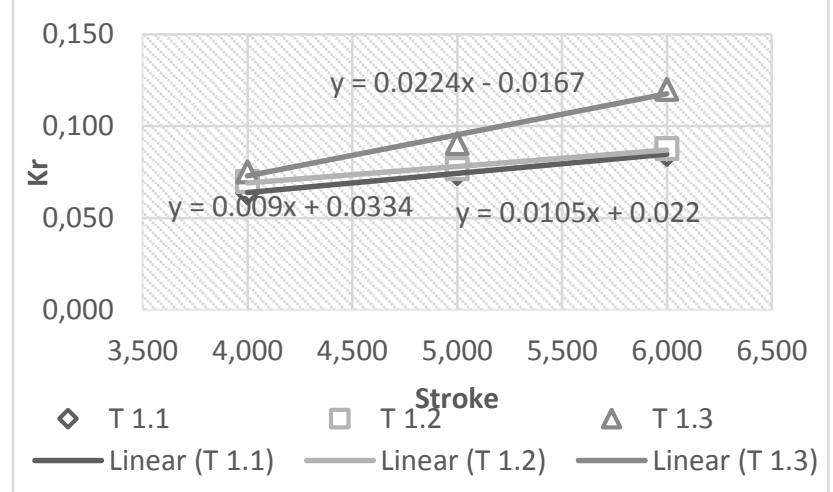

Gambar 14. Grafik hubungan $K r$ vs $T$ model tipe A, $d=16 \mathrm{~cm}$

\section{Pengaruh Model Fisik Tipe B Terhadap Refleksi Gelombang}

Nilai Koefisien Refleksi (Kr) akan semakin besar ketika nilai stroknya nya bertambah besar, dengan kata lain Koefisien Refleksi berbanding lurus dengan Nilai stroke.

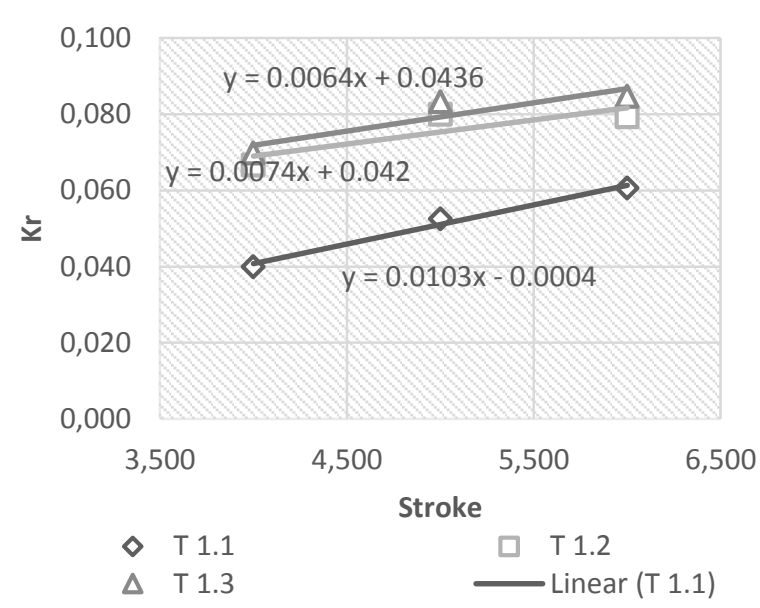

Gambar 15. Grafik Hubungan $K r$ dan Stroke model tipe $\mathrm{B}, d=16 \mathrm{~cm}$

Nilai Koefisien Refleksi (Kr) akan semakin besar ketika nilai Periodenya ( $\mathrm{T}$ ) nya bertambah besar, dengan kata lain Koefisien Refleksi berbanding lurus dengan Periode gelombang. Hubungan $\mathrm{Kr}$ dan Strike Model Tipe A disajikan pada Gambar 15.

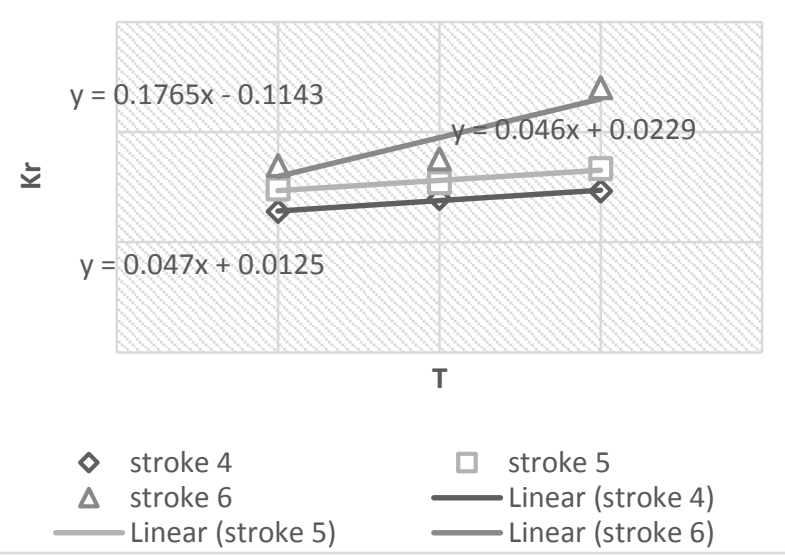

Gambar 16. Grafik hubungan $K r$ vs Stroke model tipe A, $d=16 \mathrm{~cm}$

\section{KESIMPULAN}

Parameter-parameter yang mempengaruhi refleksi gelombang pada struktur pemecah gelombang tenggelam tidak simetris berbentuk segitiga adalah kerapatan model, tinggi gelombang depan struktur $(H i)$, periode gelombang $(T)$, kedalaman air $(d)$.

Pengaruh kerapatan model terhadap refleksi gelombang $(K r)$ dapat ditafsirkan pada grafik hubungan $K r$ terhadap kerapatan model dimana nilai $K r$ semakin kecil jika nilai kerapatan nya semakin besar. Untuk pengaruh kedalaman air, nilai koefisien refleksi $(K r)$ akan semakin tinggi dengan semakin kecilnya nilai kedalaman air.

\section{DAFTAR PUSTAKA}


[1] "Pemecah Gelombang (Breakwaters)," p. 49.

[2] B. Triatmodjo, "Teknik pantai / Bambang Triatmodjo," p. 1.

[3] R. M. Azhar, A. Wurjanto, and N. Yuanita, "Studi Pengamanan Pantai Tipe Pemecah Gelombang Tenggelam di Pantai Tanjung Kait," p. 24.
[4] N. L. H. Zendrato, "Analisis Efektifitas Penggunaan Breakwater Dengan Lapis Pelindung Bambu dan Tetrapod Untuk Mereduksi Energi Gelombang Laut Di Pelabuhan Kuala Tanjung," p. 13.

[5] I. K. D. Setiawan and J. W. R. Ginting, "Refleksi Gelombang Pada Pemecah Gelombang Tenggelam Blok Beton Berkait," JTH, vol. 9, no. 1, pp. 33-42, Sep. 2018. 